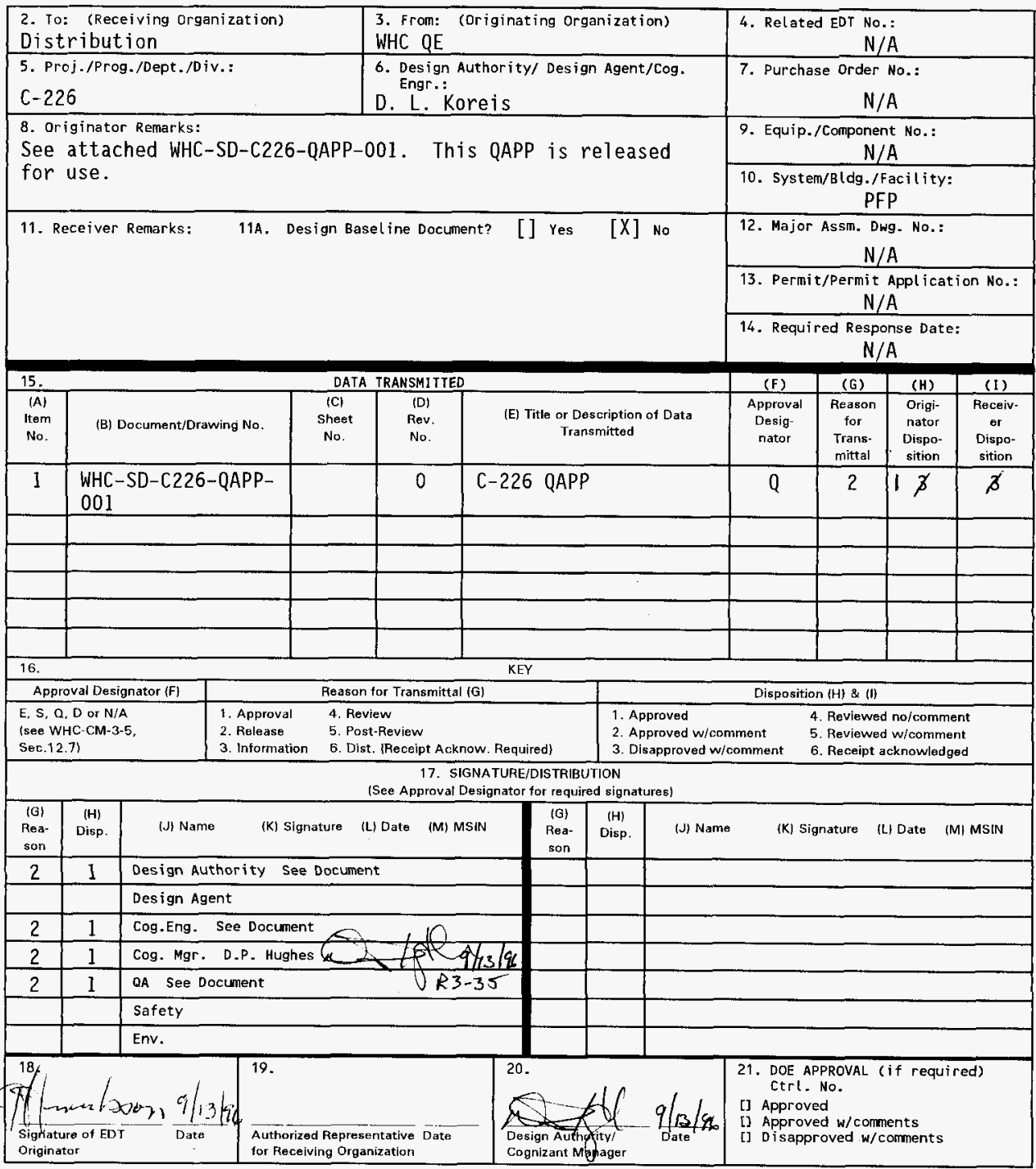




\title{
PROJECT QUALITY ASSURANCE PLAN PFP SOLUTION STABILIZATION PROJECT C-226
}

\author{
H. W. Henrikson
}

WHC, Richland, WA 99352

U.S. Department of Energy Contract DE-AC06-87RL10930

EDT/ECN: 618113

Org Code: 8KF00

B\&R Code: N/A

UC: 2050

Charge Code: $\mathrm{K} 6137$

Total Pages: $18 / 4 \mathrm{kms} \% / 17 / \mathrm{s}$

Key Words: Project Quality Assurance Plan

Abstract: This QA Plan identifies the WHC QA Program requirements for all contractors involved in the planning and execution of the design, procurement, procurement, construction, testing and inspection of Project $\mathrm{C}-226$.

TRADEMARK DISCLAIMER: Reference herein to any specific commercial product, process, or service by trade name, trademark, manufacturer, or otherwise, does not necessarily constitute or imply its endorsement, recommendation, or favoring by the United States Government or any agency thereof or its contractors or subcontractors.

Printed in the United States of America. To obtain copies of this document, contact: WHC/BCS Document Control Services, P.0. Box 1970, Mailstop H6-08, Richland WA 99352, Phone (509) 372-2420. Fax (509) 376-4989.
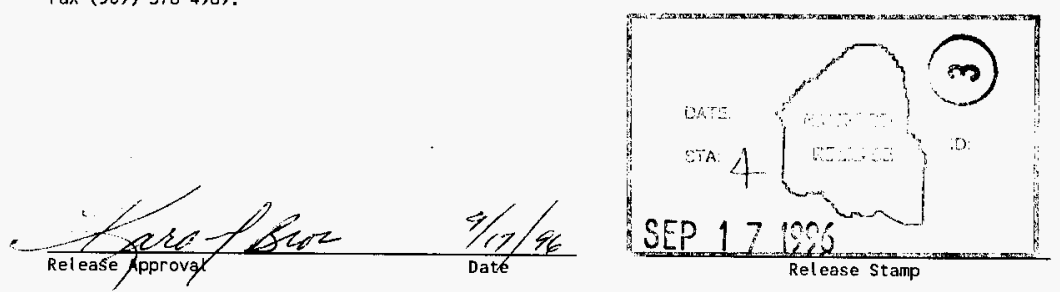

\section{Approved for Public Release}


WHC-SD-C226-QAPP-001, Rev. 0

Page 1 of 13

\section{PROJECT QUALITY ASSURANCE PLAN}

\section{PFP SOLUTION STABILIZATION}

PROJECT C-226

Issued by:

\section{WESTINGHOUSE HANFORD COMPANY}

1996

for the

\section{U.S. DEPARTMENT OF ENERGY}

RICHLAND OPERATIONS OFFICE

RICHLAND, WASHINGTON

PREPARED BY:

WHC APPROVALS:

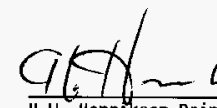

H.W. Henrikson Principat Quality Assurance Engineer Projects quality Assurance

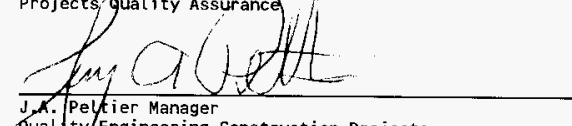

Qual ty/Engineering Construction Projects

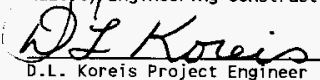

D.L. Koreis Project Engineer

Lab Transition \& Fluid Treatment Projects

DOE APPROVAL:

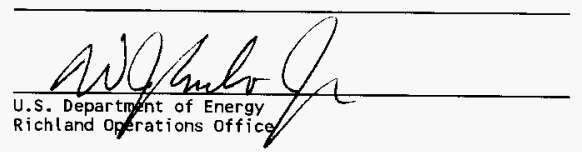

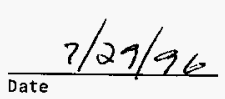
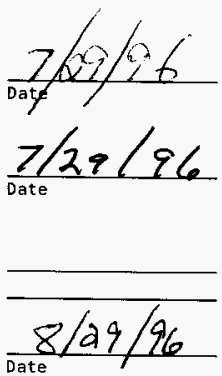
2.0 Responsibilities 3

3.0 Quality Assurance Program Requirements 5

4.0 Quality Index of Implementing Procedures 8

5.0 References 8

6.0 Attachments

6.1 Attachment 1 (QA Requirements for WHC safety classes) 09

6.2 Attachment 2 (Project Critical Characteristics) 10

6.3 Attachment 3 (Description of Types of Inspection) 12

6.4 Attachment 4 (Quality Assurance Program Index) 13 


\subsection{SCOPE}

1.1 This Quality Assurance Plan (QAP) identifies the Westinghouse Hanford Co. (WHC) Quality Assurance (QA) program requirements for all contractors involved in the planning and execution of the design, procurement, construction, testing and inspection of the PFP Solution Stabilization, Project C226. This plan provides direction for the types of verifications necessary to satisfy the functional requirements within the project scope and applicable regulatory requirements determined in the Project Functional Design Criteria (FDC), WHC-SD-CP-FDC-003.

1.2 The extent of this project Quality Assurance Plan will be for on-site design, off-site fabrication activities, and on-site installation for gloveboxes housing tanks, reactors, scrubbers, columns, pumps, and piping interconnected by encased Pu feed and return 1 ines, and chemical 1ines.

\subsection{RESPONSIBILITIES}

2.1 The Department of Energy (DOE) has the responsibility to determine the requirements for assuring quality, and the contractors are responsible for installing and implementing Quality Assurance (QA) in accordance with their contractual requirements, as stated in DOE 4700.1 , Section III, Part D.

2.2 The Operating Contractor (OC) QA Program, as described in WHC-SP-1131, complies with the requirements of 10 CFR 830.120 . This QAPP provides for top down implementation of 10 CFR 830.120 requirements and implements the OC QA Program on this project. The OC QA program provides the methods and procedures to assure compliance with 10 CFR 830.120 reqirements. For the Plutonium Finishing $\mathrm{Pl}$ ant nuclear facilities, a Standards/Requirements Identification Document (S/RID) is used to identify the set of requirements that are necessary and sufficient to provide an adequate level of protection of workers, the public, and the environment. The $O C$ is responsible for the overview of all quality related documentation for the project design, procurement, fabrication, and construction. This overview is to ensure conformance with the requirements of the Functional Design Criteria and based upon the $O C$ approved procedures.

2.3 The responsibility for the project design, procurement, fabrication, construction, and acceptance inspection shal1 be identified within the confines of the Work Breakdown Structure (WBS) located in the Project Management PIan (PMP), as prepared by the Project Engineer. The PMP will be prepared during Advanced Conceptual Design. If the responsibilities are changed during the course of the project, these changes shall be made per $O C$ approved procedures.

2.4 The 0ff-site Contractor/Fabricator is responsible and held accountable for his assigned work regarding project quality. He shall perform, or have performed, the assigned quality verification activities as 
WHC-SD-C226-QAPP-001, Rev. 0

Page 4 of 13

specified in the contract/Statement of Work and identified in the drawings, specifications and other approved project documents.

2.5 The Construction Contractor (CC) is responsible and held accountable for his assigned work regarding project quality. The $C C$ shall perform, or have performed, the assigned quality verification activities as specified in letters of instruction and identified in the drawings, specifications and other approved project documents. 


\subsection{QUALITY ASSURANCE PROGRAM REQUIREMENTS}

3.1 The design, procurement, fabrication and construction activities shall conform to the quality assurance/quality control provisions of the codes and standards specified in the approved project documents. Codes and standards shall have the edition, addenda, year, or revision identified in the Definitive Design documents (e.g. Construction Specifications and/or Drawings). These issue dates shall be based upon the start of the Definitive Design process.

3.2 The safety classification shall be determined by analysis in accordance with WHC-CM-4-46, 9.0. These procedures shall be used as a method in determining the risk involved which shall be applied to items and processes. Currently, there are only safety class 3 ( Safety Significant) items components, and structures identified in this project. A project specific Preliminary Safety Analysis Report (PSAR) will be prepared to document safety analysis information on the project.

3.3 The QA Requirements for WHC safety classes (Attachment 1) of systems, components, and structures is the basis for the requirements of this plan. They shall be used in design and construction as the basis for determining WHC quality assurance program requirements. The Project Functional Design Criteria further imposes 10 CFR 830.120 "Nuclear Safety Management Quality Assurance". The rigor with which the Quality Assurance requirements will be applied shall be based upon the a "graded approach". The identification of the safety class will assist in the application of this "graded approach" to quality.

3.4 The Project Critical Characteristics (Attachment 2) denotes the safety class and types of inspections required for typical systems, components, or structures being designed or constructed within the scope of this project. The comments section provides minimal references to suggested codes or standards to be used for direction to determine the types of inspections required to be performed. This does not relieve the Designer of the responsibility to ensure applicable requirements have been identified. The systems, components, or structures identified by Safety Classification on the Project Critical Characteristics Sheet are preliminary safety classification based upon the information supplied within the Functional Design Report. This information will be updated as necessary upon issuance of the project specific PSAR.

3.5 The Description of Types of Inspection (Attachment 3) is a detailed description of the types of inspections to be performed during the execution of construction. This description for inspection is reproduced from DOE Order 4700.1, Chapter V, Part C, Paragraph 3.c. (3) (c).

3.6 Contractors performing work on this project shall maintain a management system which addresses the applicable Quality Assurance Programmatic requirements as determined by the Safety $\mathrm{Class}$ of the systems affected. 
WHC-SD-C226-QAPP-001, Rev. 0

Page 6 of 13

It shall be the responsibility of each contractor to ensure that their sub-tier contractor complies with the applicable quality requirements as delineated herein.

3.6.1 The Architect-Engineer (A-E) who performs design activities on Safety Significant systems, components, or structures shall maintain a management system which addresses Quality Assurance Programmatic requirements of 10 CFR 830.120 "Quality Assurance." The program shall meet the applicable design function parts of the following program requirements from that standard.

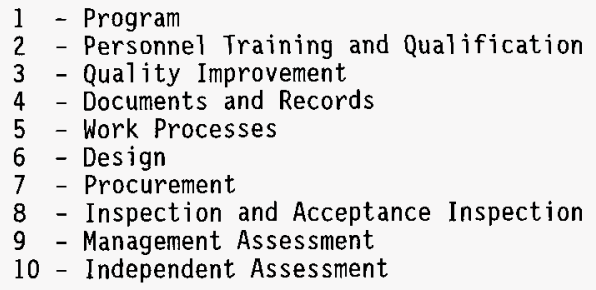

3.6.2 Those organizations performing procurement, fabrication, construction, and inspection activities on Safety Significant or non-safety class systems, components, and structures may be required to have a management system in place when addressed in the project specifications. This does not require the organization to have a formal quality assurance program, however, they may be required to have procedures and/or instructions which, as a minimum, address the following requirements:

a) PROCUREMENT DOCUMENT CONTROL - Applicable design bases and other requirements necessary to assure adequate quality shall be included or referenced in documents for procurement of items or services. Misrepresented item control shall be included.

b) DESIGN CONTROL - Design controls shall ensure correct translation of Contract requirements and design basis into design media. Controls include performance of design by qualified personnel: identification and control of design inputs and interfaces; justification, review and approval of design changes using controls which are commensurate with the original design; verification of design adequacy.

c) DOCUMENT CONTROL - The preparation, issue, and change of documents that specify quality requirements or prescribe activities affecting quality shall be controlled to assure that correct documents are being employed. 
d) INSPECTION - Inspections shall be planned. Characteristics to be inspected and inspection methods shall be specified. Inspections shall be documented. Inspection for acceptance shall be performed by persons other than those who performed or directly supervised the work being inspected.

e) TEST CONTROL - Tests required to verify conformance or demonstrate performance shall be planned and executed. Test results shall be documented and their conformance with acceptance criteria evaluated.

f) INSTRUCTIONS, PROCEDURES, AND DRAWINGS - Activities affecting quality shall be prescribed by and performed in accordance with documented instructions, procedures, or drawings of a type appropriate to the circumstances.

g) CONTROL OF MEASURING AND TEST EQUIPMENT - Measuring and test equipment used for activities affecting quality shall be controlled and calibrated.

h) CONTROL OF NONCONFORMING ITEMS - Controls shall provide for identification, documentation, evaluation, segregation when practical, dispositioning of nonconforming items, and for notification to affected organizations.

i) QUALITY ASSURANCE RECORDS - Records that furnish documentary evidence of quality shall be specified, prepared, and maintained. Records shall be legible, identifiable, and retrievable. Records shall be protected against damage, deterioration, or loss. Requirements and responsibilities for record transmittal, distribution, retention, maintenance, and disposition shall be established and documented.

j) QUALITY IMPROVEMENT - The organization shall establish and implement processes to detect and prevent quality probiems and to ensure quality improvement. Items and processes that do not meet established requirements shall be identified, controlled, and corrected. Correction sha11 include identifying the causes of problems and preventing recurrence. Item reliability, process implementation, and other quality-related information shall be reviewed and the data analyzed to identify items and processes needing improvement.

k) MANAGEMENT ASSESSMENT - Management at all levels sha11 periodically assess the integrated quality assurance program and its performance. Problems that hinder the organization from achieving its objectives shall be identified and corrected.

NOTE: For guidance as to what the procedures or instructions should address, 10 CFR 830.120, D0E 6430.1A (para. 0140), and other applicable procedures/instructions should be reviewed. 
3.6.3 Construction specifications and drawings shall specify specific code required inspection activities to be performed and to identify the responsible contractor(s) which will perform such activities.

\subsection{QUALITY INDEX OF IMPLEMENTING PROCEDURES}

4.1 An 0perating Contractor Quality Assurance Program Index (QAPI), Attachment 4, is supplied. The QAPI is a listing in Chart Format of Manuals, which contain general procedures, and some specific procedures to be utilized on the Project. The procedures from the WHC Projects Department Manuals are identified and will be applied based on the scope of the procedure. It must be noted that use of each and every procedure identified is not required for the complete project, rather, the use shall be determined by the applicable Project Engineer and the activity involved.

4.2 The engineering contractor(s) organization engaged in the activities of design verification, inspection and acceptance of project systems, components and structures shall provide an index or description of the implementing procedures to show compliance with quality programmatic requirements as required in contract documents.

4.3 The CC shall prepare and provide applicable specific procedures where required within the Definitive Design documents. All other Procedures or Methods employed shall comply with the Codes and/or Standards identified within the Definitive Design documents.

4.4 The $O C$ reviews these indexes and implementing procedures for conformance and adequacy. These documents will provide the basis for technical reviews, surveillances, and audits of project activities to assure compliance to project requirements.

\subsection{REFERENCES}

The preparation of this QAPP is based upon the following references:

1. DOE Project Management System (DOE Order 4700.1

2. US Code of Federal Regulations 10 CFR 830.120

3. WHC Quality Assurance Manual (WHC-CM-4-2)

4. WHC Management Requirements \& Procedure Manual (WHC-CM-1-3)

5. WHC Safety Analys is Manual (WHC-CM-4-46)

6. WHC Functional Design Critieria (WHC-SD-CP-FDC-003)

7. Conceptual Design Report (WHC-SD-CP-ER-043) 
WHC-SD-C226-QAPP-001, Rev. 0

Page 9 of 13

Attachment 1

QA Requirements for WHC safety classes

for Nuclear Facilities

\begin{tabular}{|c|c|c|}
\hline $\begin{array}{l}\text { WHC SAFETY } \\
\text { CLASSIFICATION* }\end{array}$ & DEF INITIONS* & $\begin{array}{l}\text { QUALITY ASSURANCE } \\
\text { REQUIREMENTS* }\end{array}$ \\
\hline safety class & $\begin{array}{l}\text { Safety class addresses } \\
\text { the offsite environment } \\
\text { and the health and safety } \\
\text { of the public. }\end{array}$ & $\begin{array}{l}\text { A comprehensive } Q A \\
\text { program that meets all } \\
\text { applicable provisions of } \\
10 \text { CFR } 830.120 \text { shall be } \\
\text { used to control a11 WHC } \\
\text { safety class items. }\end{array}$ \\
\hline Safety Significant & $\begin{array}{l}\text { Defined by items } 6 \text { through } \\
13 \text { and item } 15 \text { of Table } 1 \\
\text { in Section } 9.0 \text { of WHC-CM- } \\
4-46 \text {, Safety Analysis } \\
\text { Manual. }\end{array}$ & $\begin{array}{l}\text { A graded application of } \\
10 \text { CFR } 830.120 \text { shall be } \\
\text { used to apply QA program } \\
\text { requirements. }\end{array}$ \\
\hline $\begin{array}{c}\text { nonsafety } \\
\text { (General Services) }\end{array}$ & $\begin{array}{l}\text { Nonsafety has no } \\
\text { significant importance to } \\
\text { health, safety, or } \\
\text { environmental protection. }\end{array}$ & $\begin{array}{l}\text { No defined } Q A \text { program } \\
\text { requirements apply to } \\
\text { nonsafety items. }\end{array}$ \\
\hline
\end{tabular}


WHC-SD-C226-QAPP-001, Rev. 0

Page 10 of 13

Attachment 2

PROJECT CRITICAL CHARACTERISTICS

\begin{tabular}{|c|c|c|c|c|c|c|}
\hline \multirow{2}{*}{ ITEM } & \multirow{2}{*}{ DESCRIPTION OF ACTIVITY/SYSTEM } & \multirow{2}{*}{$\begin{array}{l}\text { SAFETY } \\
\text { CLASS }\end{array}$} & \multicolumn{3}{|c|}{$\begin{array}{l}\text { TYPE OF INSP } \\
\begin{array}{c}\text { F }=\text { FUNCTIONAL } \\
G=G E N E A A L \\
D=D E T A I\end{array}\end{array}$} & \multirow{2}{*}{ COMMENTS } \\
\hline & & & $\mathrm{F}$ & G & D & \\
\hline \multirow[t]{2}{*}{ I } & SITEWORK & -- & & & & \\
\hline & $\begin{array}{l}\text { Demolition of excess equipment } \\
\text { and piping }\end{array}$ & SS & & $x$ & & \\
\hline \multirow[t]{2}{*}{ II } & Concrete & & & & & \\
\hline & Core Drilling & SS & & $x$ & & \\
\hline \multirow[t]{14}{*}{ II I } & Metals & & & & & \\
\hline & Glovebox & SS & & $x$ & & \\
\hline & Support Anchorages & SS & & $x$ & & \\
\hline & Calciner & SS & & & & \\
\hline & Filter Bank & SS & & & $x$ & \\
\hline & Feed Storage Vessel & SS & & $x$ & & \\
\hline & Feed Pump & SS & & $x$ & & \\
\hline & Chiller & SS & & $x$ & & \\
\hline & Scrubber & SS & & $x$ & & \\
\hline & Metering Pump & SS & & $x$ & & \\
\hline & Collector Vessels & SS & & $x$ & & \\
\hline & Vacuum Trap & SS & & $x$ & & \\
\hline & Vacuum Regulator & SS & & $\mathrm{X}$ & & \\
\hline & Tank Modification & SS & & & $x$ & \\
\hline IV & Instrumentation & SS & $x$ & & & \\
\hline
\end{tabular}


WHC-SD-C226-QAPP-001, Rev. 0

Page 11 of 13

\section{Attachment 2}

\section{PROJECT CRITICAL CHARACTERISTICS}

\begin{tabular}{|c|c|c|c|c|c|c|}
\hline \multirow{2}{*}{ ITEM } & \multirow{2}{*}{ DESCRIPTION OF ACTIVITY/SYSTEM } & \multirow{2}{*}{$\begin{array}{l}\text { SAFETY } \\
\text { CLASS }\end{array}$} & \multicolumn{3}{|c|}{$\begin{array}{c}\text { TYPE OF INSP } \\
\text { F=FUNCIIONAL } \\
\text { G G GENERAL } \\
\text { D }=\text { DETALL }\end{array}$} & \multirow{2}{*}{ COMMENTS } \\
\hline & & & $F$ & $G$ & D & \\
\hline v & HVAC & SS & $x$ & & & \\
\hline \multirow[t]{7}{*}{ VI } & Piping & SS & & 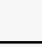 & & \\
\hline & Process Air & SS & & $x$ & & \\
\hline & Chemical Addition & SS & & $x$ & & \\
\hline & Chilled Water & SS & & $x$ & & \\
\hline & Vacuum & SS & & $x$ & & \\
\hline & Product Transfer & SS & & $x$ & & \\
\hline & Drain & SS & & $x$ & & \\
\hline VII & Electrical & ss & $x$ & & & \\
\hline & & & & & & \\
\hline & & & & & & \\
\hline & & & & & & \\
\hline & & & & & & \\
\hline & & & & & & \\
\hline & & & & & & \\
\hline & & & & & & \\
\hline & & & & & & \\
\hline & & & & & & \\
\hline & & & & 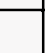 & & 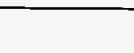 \\
\hline
\end{tabular}




\section{Attachment 3}

\section{Description of Types of Inspection}

Types of Inspection. Due to the variety and types of contracts and subcontracts, and the degree of responsibility assigned to the operating contractors, the architect-engineer, the construction contractors, and the individual vendors; specific rules covering all phases of inspection cannot be prescribed. In general, inspection activities are divided into three types: functiona 1 , general, and detailed.

1. Functional Inspection. Performed to determine overall compliance with contract drawings and specifications. Functional Inspection may vary from inspection of minor items to extensive testing of operating equipment (which must be provided for in the contract). It may also serve in making initial determination of the adequacy of the design effort. The field element and the operating contractor participate in functional inspections from the viewpoints of owner and user.

2. General Inspection. The fundamental and comprehensive inspection to ascertain that workmanship and kind and quality of materials conform to the contract specifications.

3. Detailed Inspection. Includes, but is not limited to, verification of details, such as checking location and size of reinforcing bars, maintaining records of concrete batching plant operations, verifying the use of proper welding rods, checking riveting and welding, and performing other inspection for quaTity assurance purposes. It starts with initial construction operations and extends through al1 construction stages. 
Attachment 4

Quality Assurance Program Index

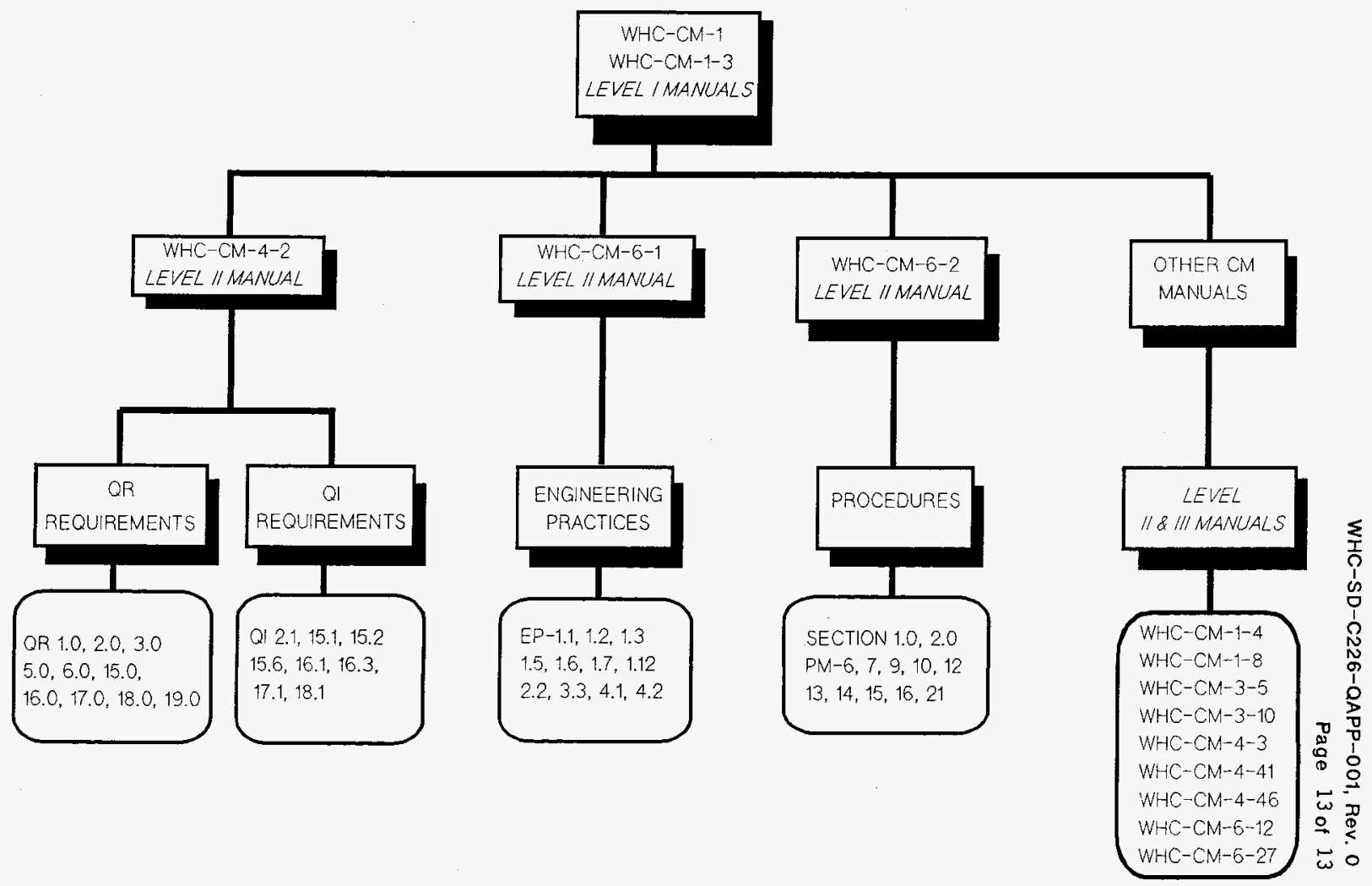




\begin{tabular}{|c|c|c|c|c|c|}
\hline \multicolumn{6}{|c|}{ DISTRIBUTION SHEET } \\
\hline To & \multirow{2}{*}{\multicolumn{2}{|c|}{ H. W. Henrikson }} & & \multicolumn{2}{|l|}{ Page 1 of 1} \\
\hline Distribution & & & ns 6000 & \multicolumn{2}{|c|}{ Date $9 / 13 / 96$} \\
\hline \multirow{2}{*}{\multicolumn{3}{|c|}{$\begin{array}{l}\text { Project Title/Work Order } \\
\text { C-226, PFP Solution Stabilization }\end{array}$}} & & \multirow{2}{*}{\multicolumn{2}{|c|}{\begin{tabular}{ll|} 
EDT No. & 618113 \\
ECN No. & N/A \\
\end{tabular}}} \\
\hline & & & & & \\
\hline Name & MSIN & $\begin{array}{l}\text { Text } \\
\text { With All } \\
\text { Attach. }\end{array}$ & Text Only & $\begin{array}{l}\text { Attach./ } \\
\text { Appendix } \\
\text { Only }\end{array}$ & $\begin{array}{l}\text { EDT/ECN } \\
\text { Only }\end{array}$ \\
\hline $\begin{array}{l}\text { H. W. Henrikson } \\
\text { D. L. Koreis } \\
\text { J. A. Peltier } \\
\text { Eng. Document Control }\end{array}$ & $\begin{array}{l}\text { R3 }-28 \\
\text { T } 5-50 \\
\text { B } 4-49 \\
\text { R } 1-29\end{array}$ & $\begin{array}{l}x \\
x \\
x \\
x\end{array}$ & & & \\
\hline
\end{tabular}

